\title{
Distribution and abundance of freshwater decapods in an Atlantic rainforest catchment with a dammed future
}

\author{
E. F. Silva-Juniora*, M. Silva-Araújo ${ }^{a}$ and T. P. Moulton ${ }^{a}$

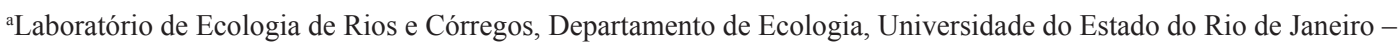 \\ UERJ, Rua São Francisco Xavier, 524, Maracanã, CEP 20550-013, Rio de Janeiro, RJ, Brazil \\ *e-mail: eduardobioadventure@gmail.com
}

Received: February 16, 2016 - Accepted: July 20, 2016 - Distributed: November 31, 2017

(With 3 figures)

\begin{abstract}
Variations in physical characteristics along the course of a river influence habitat availability which reflects in species distribution. Knowledge of ecology and diversity of lotic species is important for evaluating how river ecosystems will respond to environmental impacts. Freshwater decapods are a group of high ecological and economic importance, but the knowledge about factors influencing their distribution is scarce in Brazil. We performed a survey of decapods to describe their abundance and distribution as well as to study their relationships with stream physical variables and especially their association with different substrates types. We studied 23 sites located in 15 tributaries of Guapiaçú River, RJ, where we collected decapods in different substrates types and measured a set of physical variables. We found five decapods species, including amphidromous and non-amphidromous shrimps and crabs. Decapods were strongly associated with leaf-litter substrates and their abundance was related to a multivariate axis describing longitudinal changes in stream characteristics. We concluded that decapods occurring in the Guapiaçú catchment inhabit mainly small streams with preserved riparian forests where they find shelter and potential prey of invertebrates. The ongoing project to build a dam on the Guapiaçú River will have negative consequences to migrating shrimps and we strongly recommend that mitigating actions, such the construction of structures to allow the passage of migrating fauna, should be taken.
\end{abstract}

Keywords: shrimps, environmental factors, leaf litter, tropical stream, damming.

\section{Distribuição e abundância de decápodes de água doce e sua associação com variáveis ambientais em uma bacia hidrográfica de Mata Atlântica que será represada}

\begin{abstract}
Resumo
Variações nas características físicas de um rio ao longo do seu curso influenciam a disponibilidade de habitas e dessa forma a distribuição de espécies. O conhecimento sobre a ecologia e diversidade de espécies lóticas é importante para avaliar como esses ecossistemas responderão a impactos ambientais. Decápodes de água doce são um grupo de grande importância ecológica e econômica, contudo o conhecimento sobre fatores influenciando sua distribuição ainda é escasso no Brasil. Nós realizamos um levantamento de decápodes para descrever sua abundância e distribuição, bem como estudar sua relação com características físicas dos rios, especialmente sua associação com tipos diferentes de substrato. Nós estudamos 23 localidades distribuídas em 15 rios tributários do Rio Guapiaçú, RJ, onde coletamos decápodas em diferentes tipos de substratos e medimos um conjunto de variáveis físicas. Nós encontramos cinco espécies de decápodas incluindo camarões anfídromos e não anfídromos e caranguejos. Esses organismos foram fortemente associados a substratos de folhiço alóctone e sua abundância foi relacionada com um eixo PCA que descreve as mudanças nas características físicas longo do curso do rio. Nós concluímos que os decápodas que ocorrem na bacia do Rio Guapiaçú habitam principalmente pequenos córregos com mata ciliar preservada, onde podem encontrar abrigo e um potencial campo de caça onde predam invertebrados. O projeto atualmente em curso para a construção de uma represa no Rio Guapiaçú irá afetar negativamente a fauna de camarões anfídromos, assim nós recomendamos fortemente que ações mitigadoras, como a construção de estruturas para permitir a passagem da fauna migrante sejam tomadas.
\end{abstract}

Palavras-chave: camarões, fatores ambientais, folhiço, rios tropicais, represamento. 


\section{Introduction}

The general model describing longitudinal variation in physical characteristics of rivers along their course (i.e. the River Continuum Concept, RCC, Vannote et al., 1980) predicts that highly shaded small streams are strongly dependent upon organic matter originating from surrounding riparian forests (allochthonous material). As rivers grow in size, the relative importance of instream shading caused by riparian vegetation becomes lower and the increased light they receive stimulates instream production while the relative importance of allochthonous material to the trophic chain decreases. Variation in stream width is also related to distribution of submerged branches, leaf litter and sediment characteristics influencing habitat availability. Thus, stream size variation is a key factor influencing community structure of invertebrates (Cargnin-Ferreira and Forsberg, 2000), and fishes (Magalhães et al., 2002). Although the RCC does not make specific predictions regarding crustacean fauna, it may also be strongly influenced by these variations along the river course, but its relation is poorly studied, especially with respect to species inhabiting Atlantic forest streams (Mattos and Oshiro, 2009).

Knowledge about ecology and factors controlling distribution of freshwater species is extremely important for evaluating how biodiversity and ecosystem processes (e.g. organic matter decomposition, nutrient cycling) respond to environmental impacts and provides means for developing strategies to minimize effects of environmental changes (Postel and Carpenter, 1997). Atlantic rainforest streams have been intensely modified by land use changes and engineering actions that aim to increase water supply to agriculture, industry and human consumption. Currently, Rio de Janeiro state government is planning the construction of a dam on the Guapiaçú river (Rio de Janeiro, 2016; Britto et al., 2016), which is an important site to preserve regional biodiversity (Pereira et al., 2012). However, there is little information about aquatic biodiversity of this catchment and virtually no study about biodiversity and distribution patterns of its decapod fauna, which makes it impossible to forecast the effects and to propose actions to minimize the ecological impacts of damming the river.

Freshwater decapod crustaceans are a group of high ecological and economic importance (Silva et al., 2004; Almeida et al., 2008). Shrimps and crabs play important ecological roles in streams, processing allochthonous matter by ingestion and bioturbation (March et al., 2001; Souza and Moulton, 2005). They also act as important secondary consumers influencing invertebrate distribution (March et al., 2002; Brito et al., 2006; Moulton et al., 2004). Experimental exclusion of shrimps in an Atlantic rainforest stream led to trophic cascade effects (sensu Pace et al., 1999) reducing periphyton biomass due increase in grazer abundance and activity (Moulton et al., 2004; Souza et al., 2007) which highlights the importance of these animals in community dynamics and ecosystem process.
There are approximately 120 species of freshwater decapods in Brazil (Rocha and Bueno, 2011). Among freshwater shrimps, Palaemonidae is the most abundant family (Sampaio et al., 2009) with five genera, where Macrobrachium (Bate, 1868) is the most represented with 17 species reported from Brazilian territory (Pileggi and Mantelatto, 2010). Freshwater crabs are represented in Brazil by two families (Pseudothelphusidae and Trichodactylidae) comprising at least 50 species, most of them belonging to Trichodactylidae (Cumberlidge et al., 2014). The genus Trichodactylus (Latreille, 1828) is represented in Brazil by nine species (Mossolin and Mantelatto, 2008), and together with Macrobrachium shrimp are the most remarkable crustaceans inhabiting streams in Atlantic coastal rainforest areas. Atyid shrimps, particularly Potimirim spp, are common in streams that drain directly into the sea, but appear to be restricted in their ability to maintain populations at greater distances from the sea.

The knowledge of freshwater decapods in Brazil Atlantic coast has increased during the last decades, especially regarding their taxonomy, distribution (Bond-Buckup and Buckup, 1989; Magalhães, 2003; Magalhães et al., 2005; Mossolin and Mantelatto, 2008; Sampaio et al., 2009; Mossolin et al., 2016; Rocha and Bueno, 2011) and population structure (Ammar et al., 2001; Albertoni et al., 2002; Antunes and Oshiro, 2004; Mossolin and Bueno, 2002; Collins et al., 2006; Mattos and Oshiro, 2009). However, there is a lack of studies assessing effects of stream environmental variables on decapod communities in this area, which restricts our ability to conduct efforts for their conservation. Studies of the distribution and abundance of freshwater decapods in other places show that they can be influenced by habitat structure as well as biological interactions (Mejía-Ortíz and Alvarez, 2010). For example, Macrobrachium shrimps are negatively affected by fish (Graaf and Marttin, 2003), but are also strongly associated with stream physical variables (Iwata et al., 2003; Kemenes et al., 2010). Some studies have shown that freshwater decapod abundance is influenced by distribution of leaf litter in the river (Henderson and Walker, 1986; Kemenes et al., 2010), and in turn they positively affect decomposition rates of these materials (March et al., 2001; Moulton et al., 2010).

In this work we studied the distribution and abundance of freshwater decapods in the Guapiaçú river basin, located on the Atlantic coast of Rio de Janeiro. We performed a survey of decapods that included streams of different sizes in order to describe decapod distribution and abundance. Simultaneously, we studied the differences in decapod abundance between rock/sand and leaf litter substrates as well as their relation with a set of stream physical variables. To our knowledge this is the first work studying decapod fauna in the Guapiaçú basin and it is especially relevant given the immanent construction of a dam on the Guapiaçú river, which could have strong impacts on the decapod stream fauna. 


\section{Methodology}

\subsection{Study area}

Guapiaçú River a fifth order river in which all tributaries issue from the Serra dos Órgãos mountain range. The Guapiaçú merges with the Macacú River forming the sixth order Guapí-Macacú which flows into Guanabara Bay, RJ. We studied 23 sites located in 15 tributaries of Guapiaçú River, ranging from first to third order. All streams had headwaters located in preserved Atlantic rainforest areas, located in Três Picos State Park or in its buffer area. The geology is predominantly Precambrian granite with water conductivity ranging from 16 to $41 \mu \mathrm{S} / \mathrm{cm}$. The climate is classified as tropical Atlantic with average annual precipitation of $1300 \mathrm{~mm}$ concentrated in the summer and mean temperature of $23^{\circ} \mathrm{C}$. The study area is shown in Figure 1.

\subsection{Environmental variables}

We measured a set of stream physical variables related to habitat availability, including stream canopy cover, water temperature, stream width, and proportion of different substrates. Canopy cover was measured with a spherical densiometer (Forest densiometer, Bartlesville, OK, USA), water temperature was measured using a digital thermometer and stream width was calculated as the average of three measurements taken with tape measure. The proportion of different substrate types were estimated along $10 \mathrm{~m}$ stream channel as the average of 10 randomly distributed visual measures performed using a $0.5 \times 0.5 \mathrm{~m}$ square visual estimator. We performed all measurements between December 2015 and January 2016, which corresponds to the rain season.

\subsection{Decapod sampling}

Decapod samples were taken using traps made of PET bottles where the upper part was cut and then inverted in the same bottle creating a conical entrance. The traps were similar to those of Bentes et al. (2011), but in our case traps had just one entrance with a smaller diameter $(3.5 \mathrm{~cm})$. In second and third order streams we used twelve traps baited with canned sardine and distributed along $\approx 15 \mathrm{~m}$ of each studied site. At these locations we placed 6 traps in rock/sand substrates and 6 in leaf-litter accumulation areas, but in some sites we could not find leaf accumulations, then a complete set of twelve traps was placed in rock/sand substrates. In first order streams due their small size (less than half of $2^{\circ}$ and $3^{\circ}$ order streams width) we used only six traps distributed along a $15 \mathrm{~m}$ reach. First order streams had conspicuous accumulations of leaf litter and due to the small stream size we considered that animals inhabiting these leaf accumulations had access to the traps regardless of where they were placed, so we considered all traps in first order streams as "leaf litter traps". Traps remained in the streams for $2 \mathrm{~h}$ during the day, since we observed that a longer deployment period did not reflect in more decapod captures during a pilot sampling. Collected animals were anesthetized before killing using cold water and then stored in plastic packs with $70 \%$ alcohol to be processed at the field station. We expressed the data as absolute density that we believe to be proportional to the density of animals at the site.

Palaemonidae shrimps were classified using keys of Sampaio et al. (2009); and Mossolin et al. (2016). Trichodactylidae crabs were classified according to Magalhães (2003). All individuals were measured, sexed

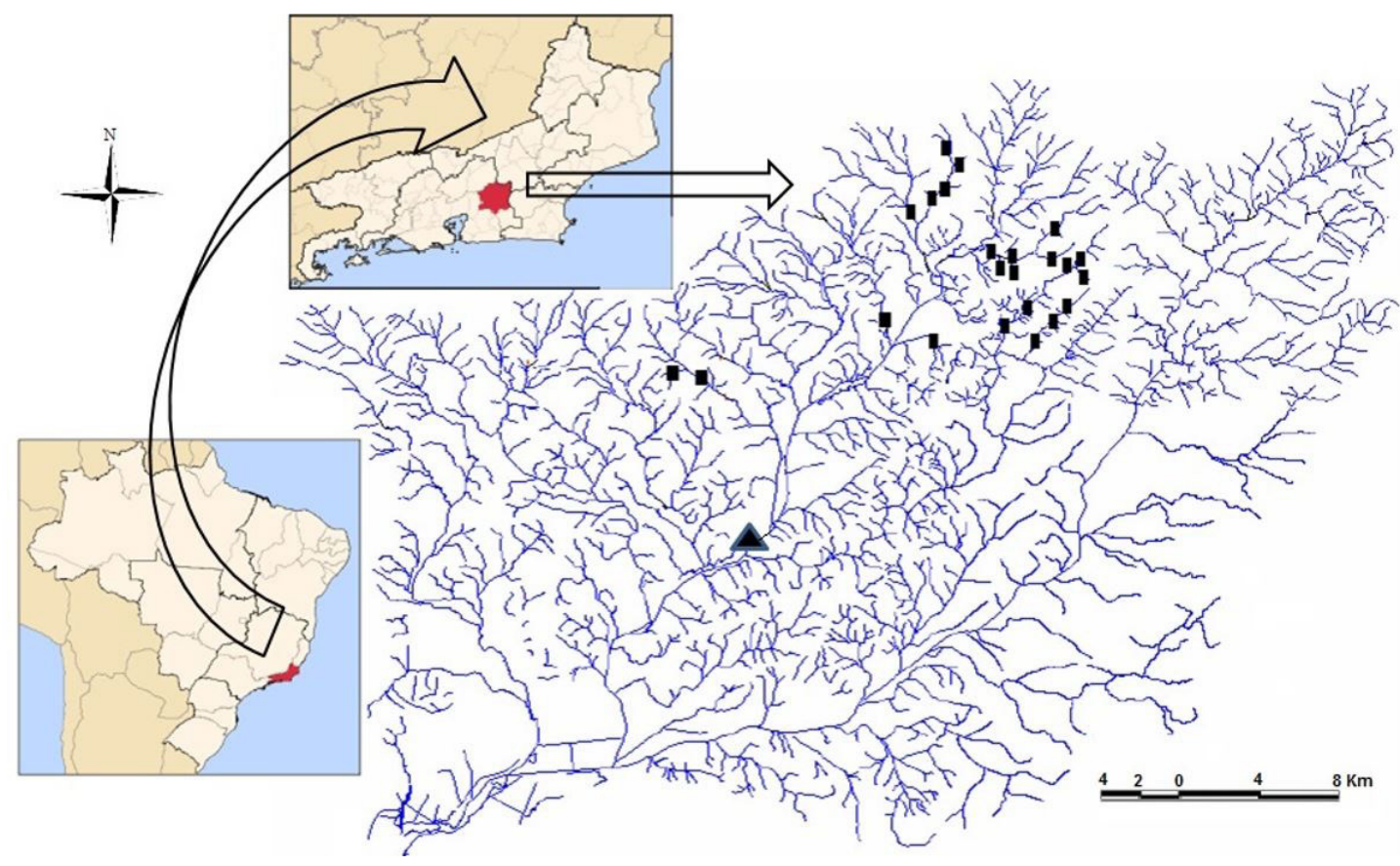

Figure 1. Guapiaçú river catchment. Squares indicates sample sites and triangle indicate the location of dam in construction. 
when possible and the number of ovigerous females was noted. Shrimp length was measure as the distance between the ocular cavity and the end of the telson. Crab size was measured as cephalothorax maximum width.

\subsection{Statistical analysis}

We compare the differences in Total Decapod Abundance (TDA) as well as in M. potiuna (Müller, 1880) and T. fluviatilis (Latreille, 1828) abundances between different substrate types using Student t-test. This statistical test was also applied to compare differences in trap capture rates between substrates types and differences in size of M. potiuna and T. fluviatilis captured in the two different substrates.

We conducted a Principal Component Analysis (PCA) in order to reduce dimensionality of our set of seven environmental variables by converting them into two orthogonal uncorrelated variables describing general environmental variation (i.e. principal components). Then we performed least square linear regression with the first principal component (which explained most of the variation in the original data set) as independent variable and TDA, M. potiuna abundance, and T. fluviatilis abundance as dependent variables. This procedure was adopted to minimize type II error probability that would be high after many comparisons using each original variable. The proportion of the variance of each original variable explained by the principal components was assessed by checking the values of the component loadings. Then to simplify the understanding of these results, the relationship between the original variables that most contribute to principal components of the decapod abundance was assessed using least squares linear regression. Since in the PCA model three variables (\%leaf litter; \% rocks; channel width) had high loading values, we additionally performed stepwise regression with these three variables as predictors of TDA. Stepwise regression indicated that \% leaf litter was the only significant variable on this new model, then we performed least squares linear regression only with this variable. All statistical analyses were performed using SPSS statistical software, IBM ${ }^{\circledR}$.

\section{Results}

Our sample sites consisted of five first order streams, five second order stream (with one sample site each) and 7 third order stream where 13 sites were distributed, totaling 23 sites distributed in 17 streams (Figure 1). These sites are located in altitudes ranging from 27 to $208 \mathrm{~m}$ above sea level and water temperature ranges from $18.4{ }^{\circ} \mathrm{C}$ to $24.8^{\circ} \mathrm{C}$ (Table 1$)$.

A total of 324 decapods were collected in 15 sites and in 8 sites there was no capture. We collected four decapod species, two Palaemonidae shrimps; Macrobrachium potiuna and Macrobrachium olfersii (Wiegmann, 1836) and two Trichodactylidae crabs; Trichodactylus fluviatilis and Trichodactylus dentatus (H. Milne-Edwards, 1853).

Table 1. Decapod abundance in the studied sites.

\begin{tabular}{|c|c|c|c|c|c|c|}
\hline Site & M.potiuna & M.olfersii & M.carcinus & T.fluviatilis & T.dentatus & TDA \\
\hline M.A $2^{\circ}$ ord & 55 & 1 & & 11 & & 67 \\
\hline M.A. $2^{\circ}$ ord (2) & 51 & & & 7 & & 58 \\
\hline M.A $3^{\circ}$ ord (1) & & & & & & 0 \\
\hline M.A $3^{\circ}$ ord (2) & 8 & 3 & & 1 & & 12 \\
\hline MRQ $1^{\circ}$ ord & & & & & & 0 \\
\hline MRQ $2^{\circ}$ ord & 16 & & & 8 & & 24 \\
\hline MRQ $3^{\circ}$ ord (1) & & & & & & 0 \\
\hline MRQ $3^{\circ}$ ord (2) & & & 1 & & & 1 \\
\hline MRQ $3^{\circ}$ ord (3) & & & & & & 0 \\
\hline MRQ $3^{\circ}$ ord (4) & & & & & & 0 \\
\hline STM $1^{\circ}$ ord (1) & 62 & & & & & 62 \\
\hline STM $1^{\circ}$ ord (2) & 1 & & & 11 & & 12 \\
\hline STM $2^{\circ}$ ord & 7 & 1 & & 15 & & 23 \\
\hline STM $3^{\circ}$ ord (1) & & 1 & & & 1 & 2 \\
\hline STM $3^{\circ}$ ord (2) & & & & & 1 & 1 \\
\hline ITA $1^{\circ}$ ord & 6 & & & 1 & & 7 \\
\hline ITA $3^{\circ}$ ord (1) & & & & 9 & & 9 \\
\hline ITA $3^{\circ}$ ord (2) & & & & 1 & & 1 \\
\hline ANL 1ord & 28 & & & & & 28 \\
\hline ANL $2^{\circ}$ ordn & 16 & & & & & 16 \\
\hline D.Barras $3^{\circ}$ ord & & & & & 2 & 2 \\
\hline Gato $3^{\circ}$ ord & & & & & & 0 \\
\hline Estreito $3^{\circ}$ ord & & & & & & 0 \\
\hline Taxon Abundance & 250 & 6 & 1 & 64 & 4 & 325 \\
\hline$\%$ of the Total & 0.77 & 0.02 & 0.00 & 0.20 & 0.01 & \\
\hline
\end{tabular}


We also registered a large individual (22.5 $\mathrm{cm}$ total length) of Macrobrachium carcinus (Linnaeus, 1758) that was caught accidently by another research group during a fish-sampling using eletrofishing, close to one of our sample sites. This specimen was noted for biodiversity survey purposes but was not considered in subsequent analyses.
M. potiuna accounted for $77 \%$ of all collected decapods and T. fluviatilis represents $20 \%$ of collected specimens. $M$. olfersii and $T$. dentatus were much less abundant representing only $2 \%$ and $1 \%$ of the captures respectively (Table 2). M. potiuna was found in ten sites and T. fluviatilis in nine. We captured only six specimens of $M$. olfersii

Table 2. Physical variables measured in the studied sites.

\begin{tabular}{|c|c|c|c|c|c|c|c|c|}
\hline Site & Coordinates & \%Shading & $\%$ Litter & \%Sand & \%Rock & $\begin{array}{c}\text { Width } \\
\text { (m) }\end{array}$ & $\begin{array}{c}\text { Temperature } \\
\left({ }^{\circ} \mathrm{C}\right) \\
\end{array}$ & $\begin{array}{c}\text { Altitude } \\
\text { (m) }\end{array}$ \\
\hline M.A $2^{\circ}$ ord & $\begin{array}{l}22^{\circ} 24^{\prime} 55.81 " \mathrm{~S} \\
42^{\circ} 44^{\prime} 15.88^{\prime \prime} \mathrm{W}\end{array}$ & 88.4 & 14.8 & 61.4 & 23.8 & 1.4 & 23.2 & 190 \\
\hline M.A. $2^{\circ}$ ord (2) & $\begin{array}{l}22^{\circ} 25^{\prime} 17.30^{\prime \prime} \mathrm{S} \\
42^{\circ} 44^{\prime} 19.59^{\prime \prime} \mathrm{W}\end{array}$ & 86.3 & 12.3 & 31.8 & 55.9 & 2.3 & 23.6 & 148 \\
\hline M.A $3^{\circ}$ ord (1) & $\begin{array}{l}22^{\circ} 24^{\prime} 51.54 ” \mathrm{~S} \\
42^{\circ} 44^{\prime} 9.91 ” \mathrm{~W}\end{array}$ & 64.7 & 5.2 & 32.9 & 61.9 & 10.6 & 23.6 & 208 \\
\hline M.A $3^{\circ}$ ord (2) & $\begin{array}{l}22^{\circ} 25^{\prime} 2.71 " \mathrm{~S} \\
42^{\circ} 44^{\prime} 15.39 " \mathrm{~W}\end{array}$ & 60.3 & 5.1 & 42.9 & 52.0 & 9.7 & 23.8 & 168 \\
\hline MRQ $1^{\circ}$ ord & $\begin{array}{l}22^{\circ} 26^{\prime} 13.29^{\prime \prime} \mathrm{S} \\
42^{\circ} 43,45.44 ” \mathrm{~W}\end{array}$ & 85.3 & 7.4 & 34.3 & 58.3 & 1.1 & 23.7 & 102 \\
\hline MRQ $2^{\circ}$ ord & $\begin{array}{l}22^{\circ} 26^{\prime} 7.24 " \mathrm{~S} \\
42^{\circ} 42^{\prime} 55.56 " \mathrm{~W}\end{array}$ & 80.1 & 9.5 & 68.5 & 22.1 & 1.6 & 23.2 & 192 \\
\hline MRQ $3^{\circ}$ ord (1) & $\begin{array}{l}22^{\circ} 25^{\prime} 52.45^{\prime \prime} \mathrm{S} \\
42^{\circ} 42^{\prime} 53.91 ” \mathrm{~W}\end{array}$ & 73.1 & 2.4 & 34.6 & 63.0 & 3.1 & 23.7 & 206 \\
\hline MRQ $3^{\circ}$ ord (2) & $\begin{array}{l}22^{\circ} 26^{\prime} 12.21^{\prime \prime} \mathrm{S} \\
42^{\circ} 43,44.64 " \mathrm{~W}\end{array}$ & 82.9 & 4.7 & 37.2 & 58.1 & 6.4 & 24.1 & 98 \\
\hline MRQ $3^{\circ}$ ord (3) & $\begin{array}{l}22^{\circ} 25^{\prime} 56.56 " \mathrm{~S} \\
42^{\circ} 44^{\prime} 15.34 " \mathrm{~W}\end{array}$ & 70.7 & 3.4 & 28.5 & 68.1 & 6.4 & 24.1 & 72 \\
\hline MRQ $3^{\circ}$ ord (4) & $\begin{array}{l}22^{\circ} 26^{\prime} 3.44 ” \mathrm{~S} \\
42^{\circ} 44^{\prime} 30.75 " \mathrm{~W}\end{array}$ & 40.6 & 2.3 & 49.4 & 48.3 & 6.4 & 24.2 & 63 \\
\hline STM $1^{\circ}$ ord (1) & $\begin{array}{l}22^{\circ} 26^{\prime} 40.14 " \mathrm{~S} \\
42^{\circ} 42^{\prime} 22.02^{\prime \prime} \mathrm{W}\end{array}$ & 94.4 & 19.4 & 59.8 & 20.8 & 1.0 & 21.8 & 184 \\
\hline STM $1^{\circ}$ ord (2) & $\begin{array}{l}22^{\circ} 26^{\prime} 40.46^{\prime \prime} \mathrm{S} \\
42^{\circ} 42^{\prime} 21.65^{\prime \prime} \mathrm{W}\end{array}$ & 90.5 & 17.2 & 49.3 & 33.4 & 1.1 & 26.8 & 185 \\
\hline STM $2^{\circ}$ ord & $\begin{array}{l}22^{\circ} 26^{\prime} 40.23 ” \mathrm{~S} \\
42^{\circ} 42^{\prime} 21.10^{\prime \prime} \mathrm{W}\end{array}$ & 89.4 & 5.7 & 35.8 & 58.5 & 4.8 & 23.0 & 200 \\
\hline STM $3^{\circ}$ ord (1) & $\begin{array}{l}22^{\circ} 27^{\prime} 25.89 " \mathrm{~S} \\
42^{\circ} 43^{\prime} 19.60^{\prime \prime} \mathrm{W}\end{array}$ & 57.0 & 5.3 & 45.4 & 49.2 & 5.1 & 23.6 & 54 \\
\hline STM $3^{\circ}$ ord (2) & $\begin{array}{l}22^{\circ} 27^{\prime} 37.21^{\prime \prime} \mathrm{S} \\
42^{\circ} 43,19.32^{\prime \prime} \mathrm{W}\end{array}$ & 3.6 & 0.0 & 44.4 & 55.6 & 2.9 & 23.9 & 48 \\
\hline ITA $1^{\circ}$ ord & $\begin{array}{l}22^{\circ} 27^{\prime} 23.99 " \mathrm{~S} \\
42^{\circ} 40^{\prime} 54.61 " \mathrm{~W}\end{array}$ & 82.2 & 12.3 & 62.2 & 25.5 & 0.9 & 18.7 & 195 \\
\hline ITA $3^{\circ}$ ord (1) & $\begin{array}{l}22^{\circ} 28^{\prime} 0.98^{\prime \prime} \mathrm{S} \\
42^{\circ} 41^{\prime} 32.05^{\prime \prime} \mathrm{W}\end{array}$ & 82.7 & 6.3 & 32.6 & 61.1 & 6.3 & 18.4 & 120 \\
\hline ITA $3^{\circ}$ ord (2) & $\begin{array}{l}22^{\circ} 28^{\prime} 16.48^{\prime \prime} \mathrm{S} \\
42^{\circ} 41^{\prime} 46.34 " \mathrm{~W}\end{array}$ & 5.7 & 0.0 & 39.2 & 60.8 & 2.2 & 19.0 & 90 \\
\hline ANL $1^{\circ}$ ord & $\begin{array}{l}22^{\circ} 29^{\prime} 35.25^{\prime \prime} \mathrm{S} \\
42^{\circ} 51^{\prime} 49.96 ” \mathrm{~W}\end{array}$ & 92.6 & 15.8 & 62.4 & 21.8 & 1.3 & 19.0 & 58 \\
\hline ANL $2^{\circ}$ ordn & $\begin{array}{l}22^{\circ} 29^{\prime} 34.61^{\prime \prime} \mathrm{S} \\
42^{\circ} 51^{\prime} 47.35^{\prime \prime} \mathrm{W}\end{array}$ & 97.1 & 13.7 & 21.6 & 64.7 & 5.8 & 23.4 & 57 \\
\hline D.Barras $3^{\circ}$ ord & $\begin{array}{l}22^{\circ} 28^{\prime} 40.39^{\prime \prime} \mathrm{S} \\
42^{\circ} 43^{\prime} 30.56^{\prime \prime} \mathrm{W}\end{array}$ & 36.4 & 0.0 & 85.3 & 14.7 & 6.7 & 24.3 & 39 \\
\hline Gato $3^{\circ}$ ord & $\begin{array}{l}22^{\circ} 26^{\prime} 8.33^{\prime \prime} \mathrm{S} \\
42^{\circ} 45^{\prime} 31.89 " \mathrm{~W}\end{array}$ & 81.1 & 5.8 & 28.6 & 65.6 & 12.0 & 23.5 & 40 \\
\hline Estreito $3^{\circ}$ ord & $\begin{array}{l}22^{\circ} 27 ' 55.94 " \mathrm{~S} \\
42^{\circ} 47,5.50 ” \mathrm{~W}\end{array}$ & 51.0 & 0.0 & 66.4 & 33.6 & 3.3 & 24.8 & 27 \\
\hline
\end{tabular}


in four sites (three streams) and only four specimens of Trichodactylus dentatus in three sites (two streams) (Table 2). Due to the high dominance of M. potiuna in the decapod communities in almost all sites, its abundance was highly correlated to total decapod abundance. Due to limitations of processing material at the field station we were not able to sex M. potiuna individuals. However we noted that approximately $14 \%$ (36) of collected $M$. potiuna specimens were ovigerous females. The sex ratio $(\mathrm{M} / \mathrm{F})$ in T. fluviatilis was 0.69 and we found no ovigerous female.

Decapods were more abundant in leaf litter substrates (251 specimens) than in rock/sand areas (73 specimens) and statistical tests found difference in total decapod abundance between different substrate types $(\mathrm{t}=2.96 \mathrm{p}<0.008)$. Accounting for each species separately M. potiuna and T. fluviatilis, were more abundant in leaf litter accumulations, but the difference was significant just for M. potiuna $(\mathrm{t}=2.56$ $\mathrm{p}=0.018$ ). Average capture rate was $81.7 \%$ for leaf litter traps and $36.11 \%$ for rock/sand traps and this difference was also statistically significant $(t=5.2 \mathrm{p}<0.001)$. There was no statistical difference when comparing variation in M. potiuna and T. fluviatilis sizes between substrate types. Differences in trap capture ratio and total decapod abundance are presented graphically in Figure 2.

Principal components analysis reduced our set of 7 environmental variables to two orthogonal axes that accounted for $\approx 65 \%$ of the variability of the original data set. The first axis explained most of the original data variance and was largely influenced by leaf litter and rock percent and channel width. This axis represents longitudinal changes in the streams starting in lower parts (piedmont streams) where streams are large, less shaded, with high percent of rock cover and less leaf litter accumulation and going in the upstream direction to where streams are small and highly shaded. The component loadings showing the relative importance of each environmental variable to PCA axis is presented in Table 3 .

We found a statistically significant relationship between the first PCA-axis and total decapod abundance $(\mathrm{p}=0.002$;

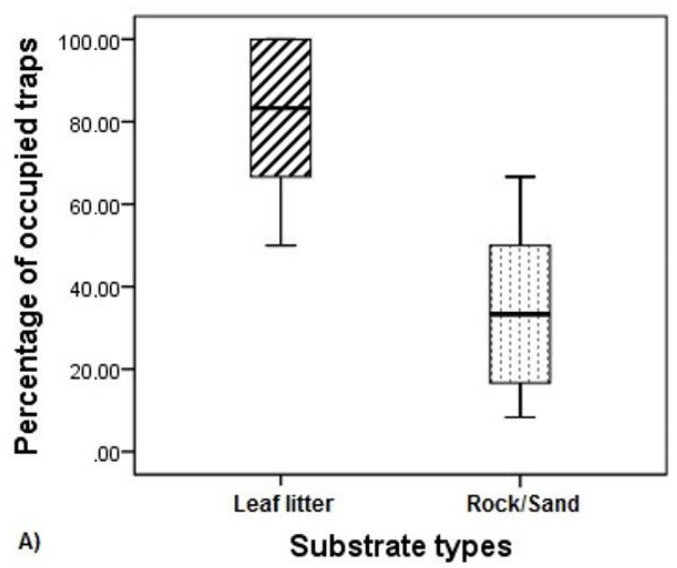

$\mathrm{R}^{2}=0.40$ ) (Figure $3 \mathrm{~A}$ ), as well as with M. potiuna total abundance $\left(\mathrm{p}=0.003 ; \mathrm{R}^{2}=0.37\right)$ while no significant relation was found for T. fluviatilis. We performed linear regressions using $\%$ of leaf litter as the predictor variable, since it had a large influence on PCA axis 1 and was indicated as a significant predictor of TDA by stepwise regression procedure. We found significant relationships of $\%$ leaf litter with TDA ( $\left.\mathrm{p}=0.001 ; \mathrm{R}^{2}=0.48\right)$ (Figure $3 \mathrm{~B}$ ) and $M$. potiuna abundance $\left(\mathrm{p}=0.001 ; \mathrm{R}^{2}=0.47\right)$, but the relationship was not significant with $T$. fluviatilis abundance.

\section{Discussion}

Decapods, and especially shrimps look to be scarce and present a restricted distribution in Guapiacú river catchment when compared with other coastal catchments (Ammar et al., 2001; Mattos and Oshiro, 2009; Silveira, 1997), but this is difficult to confirm due to differences in sampling techniques. We found species that have different reproductive strategies: Trichodactylidae crabs and M. potiuna shrimp are freshwater specialized species that have the entire life cycle in freshwater, while $M$. olfersii and M. carcinus are amphidromous (Silveira, 1997) and depend on estuarine brackish water for the development of the first stages of larval growth. Eggs are released in freshwater and are carried to the estuary where larval stages

Table 3. Contribution of original variables to the PCA components (axes). Higher absolute values mean greater contribution to the axes.

\begin{tabular}{ccc}
\hline Variable & Component 1 & Component 1 \\
\hline \%Shading & 0.546 & 0.728 \\
\%Litter & 0.81 & 0.426 \\
\%Sand & 0.667 & -0.648 \\
\%Rock & -0.857 & 0.431 \\
Width & -0.708 & 0.165 \\
Temperature & -0.183 & 0.232 \\
Altitude & 0.391 & 0.557 \\
\hline
\end{tabular}

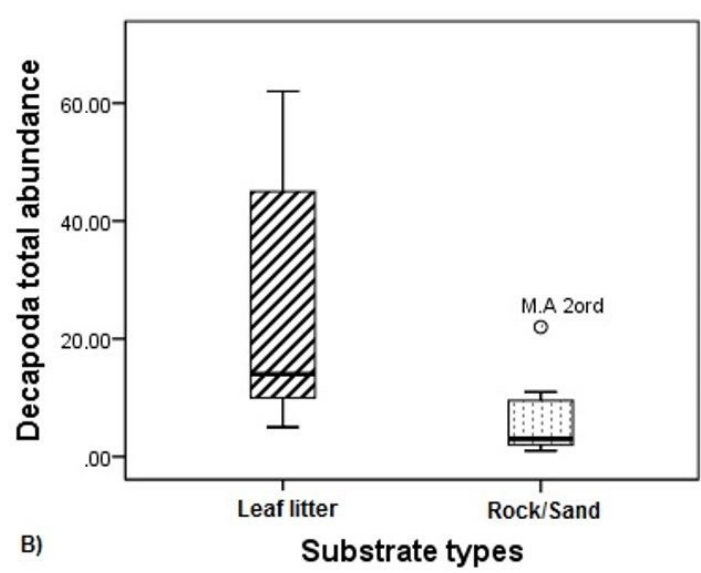

Figure 2. Difference in trap capture ratio (A) and in decapod total abundance (B) between different substrates. 
A)

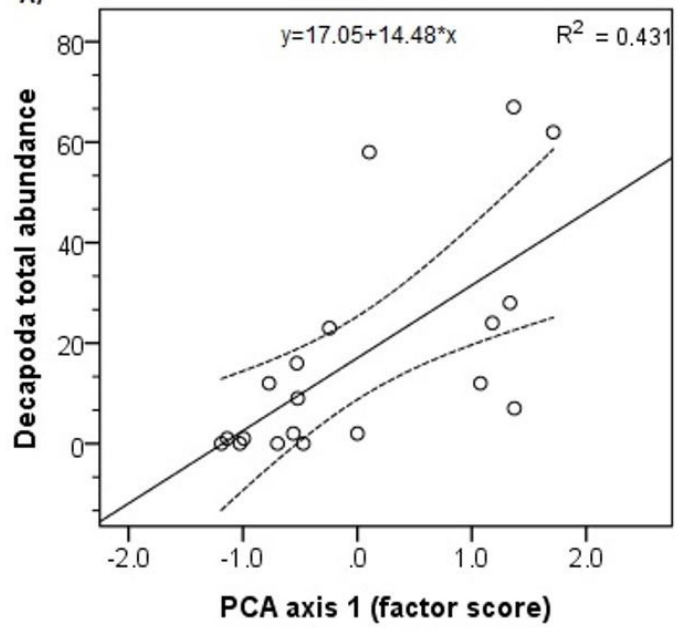

B)

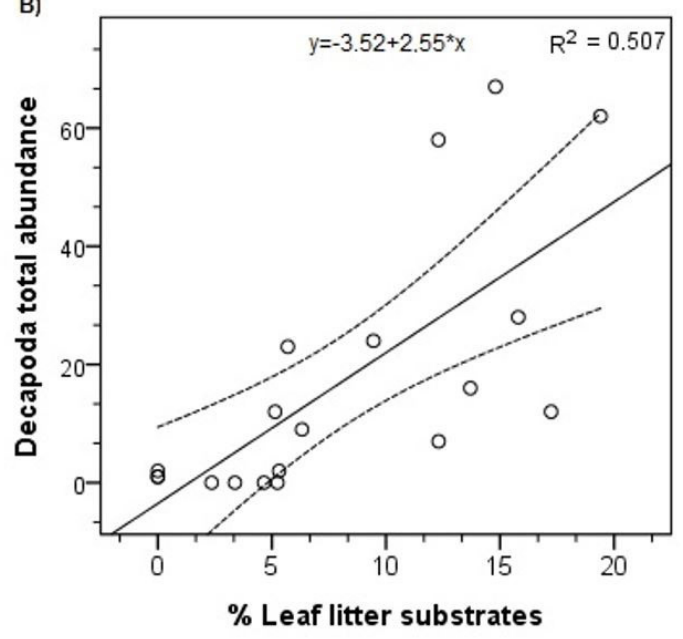

Figure 3. Relationship between decapods total abundance and: PCA first axis (A), and percentage of leaf-litter substrates (B).

feed on plankton (Bertini et al., 2014). After completing planktonic larval development juveniles start to migrate upstream and finally reach headwaters where they find more suitable conditions for their benthic feeding habits during adult life (Jalihal et al., 1993; Collart and Magalhães, 1994; Bauer, 2011). Thus, the presence of these amphidromous species in a catchment indicates that the river system maintains its ecological connectivity.

These considerations are especially important given the current plans for damming Guapiaçú River, which could prevent shrimps to complete these migrations successfully causing their local extinction (Holmquist et al., 1998). Moreover, considering that Palaemonidae shrimps interact strongly with benthic invertebrates and their experimental exclusion result in community and ecosystem level alterations (Moulton et al., 2004; Souza et al., 2007), local extinction of these shrimps will probably lead to ecosystem level effects, as reported for streams surrounding Rio de Janeiro city (Moulton et al., 2007). Thus, we strongly recommend that the project for damming Guapiaçú river must include structures to allow the passage of migrating shrimps (e.g., shrimp ladders: March et al., 2003; Fièvet, 2000).

M. carcinus is considered to be an endangered species by the Brazilian Environment Institute (IBAMA, 2016) and is under threat in Rio de Janeiro (Moulton et al., 2000; Mazzoni et al., 2009). It is frequently caught by the local population for eating. Given its large size, M. carcinus is not susceptible to be captured in our PRT traps (except for young individuals) but its presence was reported to us by the local population especially in ITA stream.

In this study we collected only four individuals of Trichodactylus dentatus that were found only in downstream reaches of two rivers (where T. fluviatilis were absent) and always in sand/rock substrates. We collected no Atyidae shrimps in the traps and did not observe them. Potimirim brasiliana is very common in small, coastal, streams, especially in places without fish (Moulton et al.,
2013). It is amphidromous, and because it is much smaller than other amphidromous Macrobrachium species, it possibly does not have as strong ability to inhabit upstream locations compared to these species. Thus we cannot infer that its absence from the Guapiaçu sites was caused by downstream impacts or by an innate difficulty in reaching and surviving in sites far from the estuary.

Decapods and especially M. potiuna were strongly associated with leaf litter accumulations in the streambed, which was demonstrated by the differences in abundance and trap capture ratio between substrates as well as by the positive relationship between their abundance and the proportion of leaf litter substrate (and also by the large contribution of this variable to PCA axis-1). Similar results were also found in the work of Bentes et al. (2011) studying M. amazonicum in brackish water environment. Despite the lack of difference in T. fluviatilis abundance, more individuals were collected in leaf litter substrates, thus, given the limited number of observations (only 64 specimens) we believe that a more intense sampling could reveal a pattern similar to that observed for M. potiuna.

The strong association of decapods with leaf litter substrates is interesting, since studying the same catchment and based on stable isotope data Lima (2009) concluded that M. potiuna and Trichodactylus sp. are secondary consumers, which have as basal food source periphyton algae which usually grows on rocks. Similar results were also found in other Atlantic rainforest stream in Rio de Janeiro (Brito et al., 2006; Neres-Lima et al., 2016). We believe that is possible that these animals are using leaf accumulations as shelter during daylight hours or even that they prey on invertebrates in the litter. However, in the studies cited above, no first order stream was studied, and the inherent limitation of algal production in small heavily-shaded streams cannot be judged. Thus it is possible that M. potiuna and T. fluviatilis derive their diet from litter in these circumstances. 
Most of the decapods collected in this study were found in small first or second order streams, while they were absent or occurred in low densities in third order streams. This was particularly so in the case of M. potiuna. Decapods were found in only 6 of the 13 third-order researched sites and usually represented by few individuals and $M$. potiuna was found in only one third-order stream. The scarcity of decapods in third order streams was independent of their association with leaf litter accumulations, since many times they were not found in these sites even when sampling this substrate.

Recently we performed a fish sample in many of the same sites recording twenty one fish species that were mainly concentrated in third order streams (unpublished data) and $M$. olfersii that was the only decapod species found during this survey. During the present work we accidently collected some fish specimens, which took place almost exclusively in third order streams, with exception of the site MRQ $1^{\circ}$ ord where we collected Phalloceros tupinambis. MRQ $1^{\circ}$ ord was the only first order stream where we collected no shrimp (but M. potiuna and Phalloceros tupinambis occurred together in STM $1^{\circ}$ ord (1). Considering this, we believe that fish can have a strong negative effect on shrimps that are excluded even when suitable abiotic conditions exist. This negative fish effect was reported for other rainforest streams (Moulton et al., 2013) and in our sites it seems to affect especially $M$. potiuna which is smaller, weaker and less aggressive than M. olfersii (Silveira, 1997; Moulton and Silveira, 1998). The distribution M. potiuna appears to be negatively affected by $M$. olfersii (Moulton and Silveira, 1998), but since $M$. olfersii was relatively rare in the studied sites, it was probably not a strong factor in restricting $M$. potiuna to smaller streams.

Relationship between decapod abundance and PCA axis-1 showed that other factors such as stream width, canopy cover and percent of rock substrates are also important environmental factors related to decapod abundance. This relationship summarizes the influence of the stream continuity in decapod abundance (especially M. potiuna), where shrimps become more abundant when the river becomes small, more shaded, with more leaf substrates and with less fish in higher altitudes.

We conclude that the Guapiaçú decapod fauna and especially $M$. potiuna are related to small streams with preserved riparian forests where they find shelter to avoid fish predation (especially M. potiuna) and possibly a good feeding site to prey on invertebrates. M. olfersii and $M$.carcinus are less subject to fish predation and use mainly rivers to complete their life cycle, so the presence of these species indicated that these animals still have the ability to migrate upstream which could change after the construction of a dam on the Guapiaçú river especially if no mitigating action is taken.

\section{Acknowledgements}

We thank Fundação SOS Mata Atlântica and Brasil Kirin S.A. for financially supporting our research. We thank Thiago Barros Lennon who collected the specimen of M. carcinus described in this work. We also thank Reserva Ecológica do Guapiaçú (REGUA) for hosting us and helping with field logistics. Eduardo Francisco da Silva-Junior thanks CAPES and Programa de Pós-graduação em Ecologia e Evolução - UERJ for his PhD scholarship.

\section{References}

ALBERTONI, E.F., PALMA-SILVA, C.A. and ESTEVES, F.D.A., 2002. Distribution and growth in adults of Macrobrachium acanthurus Wiegmann, (Decapoda, Palaemonidae) in a tropical coastal lagoon, Brazil. Revista Brasileira de Zoologia, vol. 19, no. 2, pp. 61-70.

ALMEIDA, A.O.A., COELHO, P.A., LUZ, J.R., SANTOS, J.T.A. and FERRAZ, N.R., 2008. Decapod crustaceans in fresh waters of southeastern Bahia, Brazil. Revista de Biologia Tropical, vol. 56, no. 3, pp. 1225-1254. PMid:19419041.

AMMAR, D., MÜLLER, Y.M.R. and NAZARI, E.M., 2001. Biologia reprodutiva de Macrobrachium olfersii (Wiegman) (Crustacea, Decapoda, Palaemonidae) coletados na Ilha de Santa Catarina, Brasil. Revista Brasileira de Zoologia, vol. 18, no. 2, pp. 529-537. http://dx.doi.org/10.1590/S0101-81752001000200024.

ANTUNES, L.S. and OSHIRO, L.M.Y., 2004. Aspectos reprodutivos do camarão de água doce Macrobrachium potiuna (Müller)(Crustacea, Decapoda, Palaemonidae) na serra do Piloto, Mangaratiba, Rio de Janeiro, Brasil. Revista Brasileira de Zoologia, vol. 21, no. 2, pp. 261-266. http://dx.doi.org/10.1590/ S0101-81752004000200015.

BAUER, R.T., 2011. Amphidromy and migrations of freshwater shrimps. I. Costs, benefits, evolutionary origins, and an unusual case of amphidromy. New Frontiers in Crustacean Biology, vol. 15, pp. 145-156. [Brill.] http://dx.doi.org/10.1163/ ej.9789004174252.i-354.108.

BENTES, B.S., MARTINELLI, J.M., SOUZA, L.S., CAVALCANTE, D.V., ALMEIDA, M.C. and ISAAC, V.J., 2011. Spatial distribution of the amazon river prawn Macrobrachium amazonicum (Heller, 1862)(Decapoda, Caridea, Palaemonidae) in two perennial creeks of an estuary on the northern coast of Brazil (Guajará Bay, Belém, Pará). Brazilian Journal of Biology $=$ Revista Brasileira de Biologia, vol. 71, no. 4, pp. 925-935. http://dx.doi.org/10.1590/ S1519-69842011000500013.

BERTINI, G., BAEZA, J.A. and PEREZ, E., 2014. A test of largescale reproductive migration in females of the amphidromous shrimp Macrobrachium acanthurus (Caridea: Palaemonidae) from south-eastern Brazil. Marine \& Freshwater Research, vol. 65 , no. 1 , pp. 81-93.

BOND-BUCKUP, G. and BUCKUP, L., 1989. Os Palaemonidae de águas continentais do Brasil meridional (Crustacea, Decapoda). Brazilian Journal of Biology $=$ Revista Brasileira de Biologia, vol. 49, no. 4, pp. 883-896.

BRITO, E.F., MOULTON, T.P., SOUZA, M.L. and BUNN, S.E., 2006. Stable isotope analysis indicates microalgae as the predominant food source of fauna in a coastal forest stream, south-east Brazil. Austral Ecology, vol. 31, no. 5, pp. 623-633. http://dx.doi.org/10.1111/j.1442-9993.2006.01610.x.

BRITTO, A.L., JOHNSSON, R.M.F. and CARNEIRO, P.R.F., 2016. Water supply and hydrosocial scarcity in the Rio de Janeiro Metropolitan Area. Ambiente \& Sociedade, vol. 19, no. 1, pp. 183-206. http://dx.doi.org/10.1590/1809-4422ASOC150159R1V1912016. 
CARGNIN-FERREIRA, E. and FORSBERG, B.F., 2000. Trophic structure of macroinvertebrate communities in the Jaú River System (Central Amazon, Brazil). Brazilian Journal of Ecology, vol. 3, pp. 59-66.

COLLART, O.O. and MAGALHÃES, C., 1994. Ecological constraints and life history strategies of palaemonid prawns in Amazonia. Verhandlungen - Internationale Vereinigung für Theoretische und Angewandte Limnologie, vol. 25, pp. 2460-2467.

COLLINS, P.A., GIRI, F. and WILLINER, V., 2006. Population dynamics of Trichodactylus borellianus (Crustacea Decapoda Brachyura) and interactions with the aquatic vegetation of the Paraná River (South America, Argentina). Annales de LimnologieInternational Journal of Limnology, vol. 42, no. 1, pp. 19-25. http://dx.doi.org/10.1051/limn/2006001.

CUMBERLIDGE, N., ALVAREZ, F. and VILLA-LOBOS, J.L., 2014. Results of the global conservation assessment of the freshwater crabs (Brachyura, Pseudothelphusidae and Trichodactylidae): the Neotropical region, with an update on diversity. ZooKeys, no. 457, pp. 133-157. PMid:25561834.

FIÈVET, É., 2000. Passage facilities for diadromous freshwater shrimps (Decapoda: Caridea) in the Bananier River, Guadeloupe, West Indies. Regulated Rivers: Research and Management, vol. 16, pp. 101-112. http://dx.doi.org/10.1002/(SICI)10991646(200003/04)16:2<101::AID-RRR569>3.0.CO;2-T.

GRAAF, G. and MARTTIN, F., 2003. Mechanisms behind changes in fish biodiversity in the floodplains of Bangladesh. Wetlands Ecology and Management, vol. 11, no. 5, pp. 273-280. http:// dx.doi.org/10.1023/B:WETL.0000005539.40722.48.

HENDERSON, P.A. and WALKER, I., 1986. On the leaf litter community of the Amazonian blackwater stream Tarumazinho. Journal of Tropical Ecology, vol. 2, no. 1, pp. 1-16. http://dx.doi. org/10.1017/S0266467400000547.

HOLMQUIST, J.G., SCHMIDT $\square$ GENGENBACH, J.M. and YOSHIOKA, B.B., 1998. High dams and marine $\square$ freshwater linkages: effects on native and introduced fauna in the Caribbean. Conservation Biology, vol. 12, no. 3, pp. 621-630. http://dx.doi. org/10.1046/j.1523-1739.1998.96427.x.

INSTITUTO BRASILEIRO DO MEIO AMBIENTE - IBAMA [online], 2016 [viewed 24 June 2016]. Available from: http:// www.ibama.gov.br/institucional/lista-de-especies-aquaticasameacadas-de-extincao

IWATA, T., INOUE, M., NAKATO, S., MIYASAKA, H., DOI, A. and COVICH, A.P., 2003. Shrimp abundance and habitat relationships in tropical rain-forest streams, Sarawak, Borneo. Journal of Tropical Ecology, vol. 19, no. 4, pp. 387-395. http:// dx.doi.org/10.1017/S0266467403003432.

JALIHAL, D.R., SANKOLLI, K.N. and SHENOY, S., 1993. Evolution of larval developmental patterns and the process of freshwaterization in the prawn genus Macrobrachium Bate, 1868 (Decapoda, Palaemonidae). Crustaceana, vol. 65, no. 3, pp. 365376. http://dx.doi.org/10.1163/156854093X00793.

KEMENES, A., FORSBERG, B.R., MAGALHÃES, C. and ANJOS, H., 2010. Environmental factors influencing the community structure of shrimps and crabs (Crustacea: Decapoda) in headwater streams of the Rio Jaú, Central Amazon, Brazil. Pan-American Journal of Aquatic Sciences, vol. 5, no. 1, pp. 36-46.

LIMA, V.N., 2009. Estudos de estruturas tróficas e de impactos antropogênicos de córregos do sistema hidrográfico Guapi-Macacu: isótopos estáveis. Rio de Janeiro: Universidade do Estado do Rio de Janeiro, 51 p. Masters Dissertation.

MAGAlHÃES, C., 2003. Famílias Pseudothdphusidae e Trichodactylidae. In: G. A. S. MELO, ed. Manual de identificação dos Crustacea: decapoda de água doce do Brasil. São Paulo: Edições Loyola, pp. 143-287.

MAGALHÃES, C., BUENO, S.L.S., BOND-BUCKUP, G., VALENTI, W.C., SILVA, H.M., KIYOHARA, F., MOSSOLIN, E.C. and ROCHA, S.S., 2005. Exotic species of freshwater decapod crustaceans in the state of São Paulo, Brazil: records and possible causes of their introduction. Biodiversity and Conservation, vol. 14, no. 8, pp. 1929-1945. http://dx.doi.org/10.1007/s10531-004-2123-8.

MAGALHÃES, M.F., BATALHA, D.C. and COLLARESPEREIRA, M.J., 2002. Gradients in stream fish assemblages across a Mediterranean landscape: contributions of environmental factors and spatial structure. Freshwater Biology, vol. 47, no. 5, pp. 1015-1031. http://dx.doi.org/10.1046/j.1365-2427.2002.00830.x.

MARCH, J.G., BENSTEAD, J.P., PRINGLE, C.M. and RUEBEL, M.W., 2001. Linking shrimp assemblages with rates of detrital processing along an elevational gradient in a tropical stream. Canadian Journal of Fisheries and Aquatic Sciences, vol. 58, no. 3, pp. 470-478. http://dx.doi.org/10.1139/f00-263.

MARCH, J.G., BENSTEAD, J.P., PRINGLE, C.M. and SCATENA, F.N., 2003. Damming tropical island streams: problems, solutions, alternatives. Bioscience, vol. 53, no. 11, pp. 1069-1078. http:// dx.doi.org/10.1641/0006-3568(2003)053[1069:DTISPS]2.0.CO;2.

MARCH, J.G., PRINGLE, C.M., TOWNSEND, M.J. and WILSON, A.I., 2002. Effects of freshwater shrimp assemblages on benthic communities along an altitudinal gradient of a tropical island stream. Freshwater Biology, vol. 47, no. 3, pp. 377-390. http:// dx.doi.org/10.1046/j.1365-2427.2002.00808.x.

MATTOS, L.A. and OSHIRO, L.M.Y., 2009. Estrutura populacional de Macrobrachium potiuna (Crustacea, Palaemonidae) no Rio do Moinho, Mangaratiba, Rio de Janeiro, Brasil. Biota Neotropica, vol. 9, no. 1, pp. 81-86. http://dx.doi.org/10.1590/ S1676-06032009000100010.

MAZZONI, R., FIGUEIREDO, C.A.A.D., ENRICI, M.C., BAPTISTA, D.F., CARAMASCHI, E.P., NESSIMIAN, J.L., PAZ, R.C.D., THIENGO, S.C., GUEDES, D.M. and MOULTON, T.P., 2009. Organismos aquáticos nos sistemas fluviais do Rio de Janeiro. In: H. G. BERGALLO, E. C. C. FIDALGO, C. F. D. ROCHA, M. C. UZÊDA, M. B. COSTA, M. A. S. ALVES, M. V. SLUYS, M. A. SANTOS, T. C. C. COSTA and A. C. R. COZZOLINO, eds. Estratégias e ações para a conservação da biodiversidade no Estado do Rio de Janeiro. Rio de Janeiro: Instituto Biomas, pp. 153-174.

MEJÍA-ORTÍZ, L.M. and ALVAREZ, F., 2010. Seasonal patterns in the distribution of three species of freshwater shrimp, Macrobrachium spp., along an altitudinal river gradient. Crustaceana, vol. 83, no. 4, pp. 385-397. http://dx.doi.org/10.1163/001121610X489368.

MOSSOLIN, E.C. and BUENO, S.L., 2002. Reproductive biology of Macrobrachium olfersi (Decapoda, Palaemonidae) in São Sebastião. Brazilian Journal of Crustacean Biology, vol. 22, no. 2, pp. 367-376. http://dx.doi.org/10.1163/20021975-99990244.

MOSSOLIN, E.C. and MANTELATTO, F.L., 2008. Taxonomic and distributional results of a freshwater crab fauna survey (Family Trichodactylidae) on São Sebastião Island (Ilhabela), South Atlantic, Brazil. Acta Limnologica Brasiliensia, vol. 20, no. 2, pp. 125-129. 
MOSSOLIN, E.C., PILEGGI, L.G. and MANTELATTO, F.L., 2016. Crustacea, Decapoda, Palaemonidae, Macrobrachium Bate, 1868, São Sebastião Island, state of São Paulo, southeastern Brazil. Check List, vol. 6, no. 4, pp. 605-613. http://dx.doi. org/10.15560/6.4.605.

MOULTON, T. P., MELO, G. A. S., NESSIMIAN, J., SALGADO, N. C., PAIVA, P. C. D., ABSALÃO, R. S., SANTOS, S. B., VELOSO, V. G. and COSTA, J. M., 2000. Invertebrados aquáticos. In: H. G. BERGALLO, C. F. D. ROCHA, M. A. S. ALVES and M. VAN SLUYS, eds. A fauna ameaçada de extinção do Estado do Rio de Janeiro. Rio de Janeiro: Editora da Universidade do Estado do Rio de Janeiro, pp. 45-52.

MOULTON, T.P. and SILVEIRA, R.M.L.,1998. Tests of association between species in extensive surveys in which individual sample size is small: case history of Macrobrachium spp. at Ilha do Cardoso, SP, Brazil. In: Anais do VIII Seminário Regional de Ecologia, 1998, São Carlos. São Carlos: Programa de Pós-graduação em Ecologia e Recursos Naturais, Universidade Federal de São Carlos, pp. 837-846.

MOULTON, T.P., MAGALHÃES-FRAGA, S.A., BRITO, E.F. and BARBOSA, F.A., 2010. Macroconsumers are more important than specialist macroinvertebrate shredders in leaf processing in urban forest streams of Rio de Janeiro, Brazil. Hydrobiologia, vol. 638, no. 1, pp. 55-66. http://dx.doi.org/10.1007/s10750-009-0009-1.

MOULTON, T.P., SOUZA, M.L. and OLIVEIRA, A.F., 2007. Conservation of catchments: some theoretical considerations and case histories from Rio de Janeiro. Neotropical Biology and Conservation, vol. 2, no. 1, pp. 28-35.

MOULTON, T.P., SOUZA, M.L., SILVEIRA, R.M. and KRSULOVIĆ, F.A., 2004. Effects of ephemeropterans and shrimps on periphyton and sediments in a coastal stream (Atlantic forest, Rio de Janeiro, Brazil). Journal of the North American Benthological Society, vol. 23, no. 4, pp. 868-881. http://dx.doi. org/10.1899/0887-3593(2004)023<0868:EOEASO>2.0.CO;2.

MOULTON, T.P., SOUZA, M.L., SILVEIRA, R.M.L., KRSULOVIĆ, F.A.M., SILVEIRA, M.P., ASSIS, J.C.F. and FRANCISCHETTI, C.N., 2013. Patterns of periphyton are determined by cascading trophic relationships in two neotropical streams. Marine \& Freshwater Research, vol. 61, no. 1, pp. 57-64. http://dx.doi. org/10.1071/MF08326.

NERES-LIMA, V., BRITO, E.F., KRSULOVIĆ, F.A.M., DETWEILER, A.M., HERSHEY, A.E. and MOULTON, T.P., 2016. High importance of autochthonous basal food source for the food web of a Brazilian tropical stream regardless of shading. International Review of Hydrobiology, vol. 101, no. 3-4, pp. 132142. http://dx.doi.org/10.1002/iroh.201601851.

PACE, M.L., COLE, J.J., CARPENTER, S.R. and KITCHELL, J.F., 1999. Trophic cascades revealed in diverse ecosystems. Trends in Ecology \& Evolution, vol. 14, no. 12, pp. 483-488. PMid:10542455. http://dx.doi.org/10.1016/S0169-5347(99)01723-1.

PEREIRA, P. S., FERNANDES, L.A.C., MOTA OLIVEIRA, J.L. and BAPTISTA, D.F., 2012. Avaliação da integridade ecológica de rios em áreas do zoneamento ecológico econômico do complexo hidrográfico Guapiaçu-Macacu, RJ, Brasil. Revista Ambiente \& Água, vol. 7, no. 1, pp. 157-168. http://dx.doi.org/10.4136/ ambi-agua.762.

PILEGGI, L.G. and MANTELATTO, F.L., 2010. Molecular phylogeny of the freshwater prawn genus Macrobrachium (Decapoda, Palaemonidae), with emphasis on the relationships among selected American species. Invertebrate Systematics, vol. 24, no. 2, pp. 194-208. http://dx.doi.org/10.1071/IS09043.

POSTEL, S. and CARPENTER, S., 1997. Freshwater ecosystem services. In: G. DAILY, ed. Nature's services: societal dependence on natural ecosystems. Washington: Island Press, pp. 195-214.

RIO DE JANEIRO. Governo do Estado [online], 2016 [viewed 27 June 2016]. Available from: http://www.rj.gov.br/web/imprensa/ exibeconteudo? article-id $=2332038$

ROCHA, S.S.D. and BUENO, S.L.D.S., 2011. Extension of the known distribution of Aegla strinatii Türkay, 1972 and a checklist of decapod crustaceans (Aeglidae, Palaemonidae and Trichodactylidae) from the Jacupiranga State Park, South of São Paulo State, Brazil. Nauplius, vol. 19, no. 2, pp. 163-167. http:// dx.doi.org/10.1590/S0104-64972011000200008.

SAMPAIO, S.R., NAGATA, J.K., LOPES, O.L. and MASUNARI, S., 2009. Camarões de águas continentais (Crustacea, Caridea) da Bacia do Atlântico oriental paranaense, com chave de identificação tabular. Acta Biológica Paranaense, vol. 38, pp. 11-34.

SILVA, R.R., SAMPAIO, C.M.S. and SANTOS, J.A., 2004. Fecundity and fertility of Macrobrachium amazonicum (Crustacea, Palaemonidae). Brazilian Journal of Biology $=$ Revista Brasileira de Biologia, vol. 64, no. 3A, pp. 489-500. PMid:15622846. http:// dx.doi.org/10.1590/S1519-69842004000300012.

SILVEIRA, R.M.L., 1997. Consequências da história de vida na ecologia das espécies de Macrobrachium Bate (Crustacea, Decapoda, Palaemonidae) na Ilha do Cardoso, SP, Brasil. Rio de Janeiro: Universidade do Estado do Rio de Janeiro, 61 p. Monograph.

SOUZA, M.L. and MOULTON, T.P., 2005. The effects of shrimps on benthic material in a Brazilian island stream. Freshwater Biology, vol. 50, no. 4 , pp. 592-602. http://dx.doi.org/10.1111/j.13652427.2005.01348.x.

SOUZA, M.L., MOULTON, T.P., SILVEIRA, R.M.L., KRSULOVIC, F.A.M. and BRITO, E.F., 2007. Responses of Chironomidae (Diptera; Insecta) to the exclusion of shrimps and Ephemeroptera in a coastal forest stream, Rio de Janeiro, Brazil. Brazilian Journal of Biology = Revista Brasileira de Biologia, vol. 67, no. 1, pp. 47-51. PMid:17505749. http://dx.doi.org/10.1590/ S1519-69842007000100007.

VANNOTE, R.L., MINSHALL, G.W., CUMMINS, K.W., SEDELL, J.R. and CUSHING, C.E., 1980. The river continuum concept. Canadian Journal of Fisheries and Aquatic Sciences, vol. 37, no. 1, pp. 130-137. http://dx.doi.org/10.1139/f80-017. 